\title{
Isolation, characterization and evaluation of antimicrobial and cytotoxic activity of estragole, obtained from the essential oil of croton zehntneri (euphorbiaceae)
}

\author{
THALLITA C.B. ANDRADE ${ }^{1}$, SIDNEY G. DE LIMA ${ }^{1}$, \\ RIVELILSON M. FREITAS ${ }^{1}$, MÁRCIO S. ROCHA ${ }^{1}$, TOREQUL ISLAM ${ }^{2}$, \\ TERESINHA G. DA SILVA ${ }^{3}$ and GARDENIA C.G. MILITÃ̃ ${ }^{3}$ \\ ${ }^{1}$ Programa de Pós-Graduação em Ciências Farmacêuticas, Departamento de \\ Bioquímica de Farmacologia, Universidade Federal do Piauí, Campus Universitário \\ Ministro Petrônio Portel, s/n, Ininga, 64049-550 Teresina, PI, Brasil \\ ${ }^{2}$ Department of Pharmacy, Faculty of Science and Engineering, Southern University \\ Bangladesh, 739/A, Mehedibag Road, Mehedibag, 4000, Chittagong, Bangladesh \\ ${ }^{3}$ Laboratório de Bioensaios para Pesquisa de Drogas, Universidade Federal de Pernambuco, \\ Av. Prof. Moraes Rego, 1235, Cidade Universitária, 50670-901 Recife, PE, Brasil
}

Manuscript received on March 6, 2014; accepted for publication on July 8, 2014

\begin{abstract}
Croton zehntneri (Euphorbiaceae) is a native aromatic plant from Northeast region of Brazil. The monoterpenoid estragole (ESL) has been isolated by classical chromatographic methods from the essential oil (EO) of C. zehnteneri leaves and characterized by GC-FID and GC-MS, its antimicrobial and cytotoxic potentials being assessed. The analysis of the EO enabled the identification of $100 \%$ of the integrated constituents, of which yield was about $1.8 \%$. The main components identified were: eucalyptol, estragole $(84.7 \%)$ and spathulenol. The dosage of $50 \mu \mathrm{g} /$ disk of ESL presented fairly significant zones of inhibition against Gram-positive bacteria and fungi. The ESL presented toxicity against Artemia salina with $\mathrm{LC}_{50}$ and $\mathrm{LC}_{90}$ of 4,54 and $8,47 \mu \mathrm{g} \mathrm{mL}^{-1}$. However, in tumor inhibition assays (human cells), there were no rewarding inhibition in any of the human cancer cell lines (MCF-7, HEP-2 and NCI-H292).
\end{abstract}

Key words: Antimicrobial, Croton zehntneri, cytotoxic, estragole.

\section{INTRODUCTION}

Infectious diseases are the world's leading cause of premature deaths (Emori and Gaynes 1993). Cancer is the cause of more than six million deaths in the world each year. In 2001, about 1,268,000 new cancer cases and 553,400 deaths were reported in the United States (Izevbigie 2003).

Correspondence to: Sidney G. de Lima

E-mail: sidney@ufpi.edu.br
Resistance to antimicrobial agents has become an increasingly important and pressing global problem. Substantial investment and research in the field of anti-infectives are now desperately needed if a public health crisis is to be averted. Structural modification of antimicrobial drugs to which resistance has developed has proven to be an effective means of extending the life-span of antifungal agents such as the azoles (Jeu et al. 2003), 
antiviral agents such as the non-nucleoside reverse transcriptase inhibitors (De Clercq 2001), and various antibacterial agents including $\beta$-lactams and quinolones (Poole 2001).

It is not surprising then, that in response to antimicrobial resistance, major pharmaceutical companies have tended to concentrate their efforts on improving antimicrobial agents in established classes (Taylor et al. 2002).

Rational drug design does not always yield effective antimicrobials. In the past, potent enzyme inhibitors have been successfully designed and synthesized but they had only modest antibacterial activity, probably owing to the complex issue of drug uptake by cells. Broad empirical screening of chemical entities for antimicrobial activity represents an alternative strategy for the development of novel drugs. Natural products have been a particularly rich source of anti-infective agents, yielding, for example, the penicillins in 1940, the tetracyclines in 1948 and the glycopeptides in 1955 (Silver and Bostian 1990).

The impact of infectious diseases is dodgy to the developing countries due to relative unavailability of medicines and the emergence of widespread drugs resistance (Zampini et al. 2009).
During the last two decades, the development of drug resistance as well as the appearance of undesirable side effects of certain antibiotics has lead to the search of new antimicrobial agents with the goal to discover new chemical structures, which overcome the above disadvantage (Okemo et al. 2003, Bounamama et al. 2006).

Observing that microorganisms resistant to antimicrobials agents represent a challenge in the treatment of infections, it is notorious the need for finding new substances with antimicrobial features to be used in future formulations of commercial products. Croton zehntneri (Figure 1) is an aromatic plant native to Northeastern Brazil, and widely distributed in the municipality of Simões, State of Piauí , Brazil, where it is popularly called "Canelinha" and used as a sedative, as an antiseptic, and for gastrointestinal disturbances.

Because of the potential activities of the essential oil of Croton zehntneri collected in different regions of Brazil (Morais et al. 2006), and possible carcinogenic and genotoxic activity documented in the literature, we decided to determine the chemical composition of the essential oil from C. zehntneri from Simões city - Brazil, and evaluate the antimicrobial and cytotoxic activities of its main component: estragole (iv).

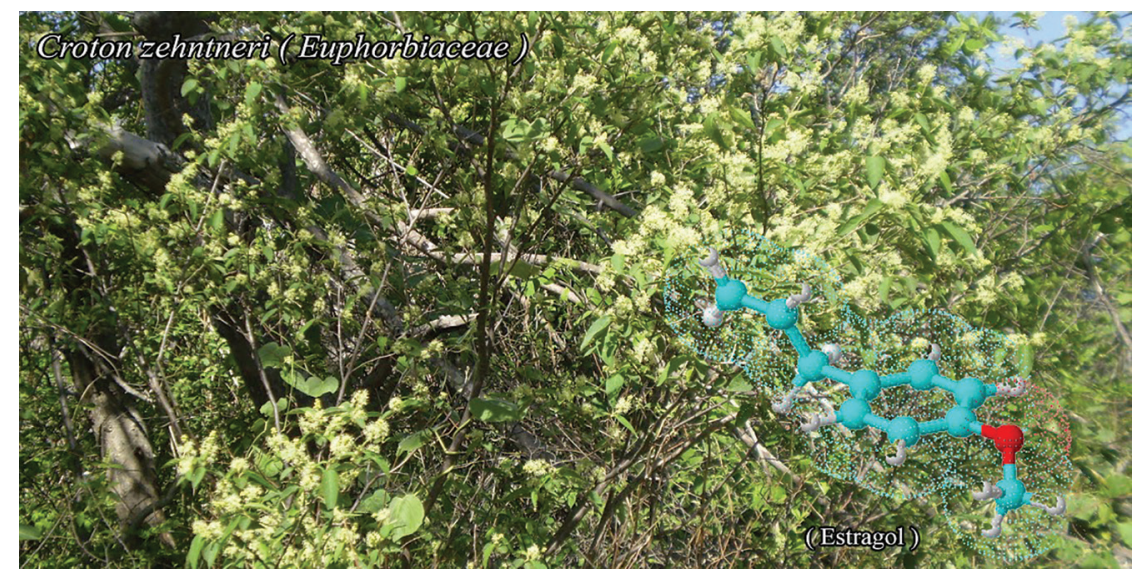

Figure 1 - Photo of a specimen of Croton zehntneri (Euphorbiaceae), showing branches and inflorescence, and structure of estragole. 


\section{MATERIALS AND METHODS}

\section{PLANT MATERIAL}

Leaves and stems of C. zehntneri (Euphorbiaceae) were collected in January of 2011 in Simões, Piauí, Brazil. The voucher specimen was collected by Dr. Sidney Lima, and identified by Dr. Roseli Farias Melo Barros (UFPI), and deposited in the Herbarium Graziela Barroso the Federal University of Piauí, Brazil, (number 27.273)

\section{EXTRACTION AND ANALYSIS}

Samples of fresh leaves and stems (about $300 \mathrm{~g}$ ) of $C$. zehntneri was subjected to hydrodistillation (4h) to obtain the essential oil, and classic column chromatography technique was used as purification of the estragole. The essential oil and pure estragole was analyzed by Shimadzu GC-17A/MS QP5050AGC-MS system according to Medeiros et al. (2012). The identity of each compound was determined by comparison of its retention index relative to $\mathrm{C}_{8}$ $\mathrm{C}_{20}$ n-alkanes (Fluka Analytical, $1.0 \mathrm{~mL}$ Alkane Standard Solution), as well as by its spectra with the database library Wiley 229. The retention data (retention indexes) were compared to those of the literature (Adams 2007). The identification of estragole (1-allyl-4-methoxybenzene) was confirmed by coinjection with standard solution (estragole analytical standard, Sigma-Aldrich).

The analyses were also carried out by Gas Chromatography with Flame Ionization Detection (GC-FID) in an Agilent 5975C instrument using a capillary column coated with DB-5 (30 m x 0.25 $\mathrm{mm}$ i.d, $0.25 \mu \mathrm{m}$ film thickness; J \& W Scientific, Folsom, CA, USA), in condition similar to GCMS above. Hydrogen was used as carrier gas. The GC-FID chromatogram was used to determine the relative concentrations using peak areas.

MICROORGANISMS

Clinical strains of human pathogenic bacteria comprising 4 Gram positive bacteria: Bacillus subtilis, B. megaterium, B. cereus and Staphylococcus aureus and 7 Gram negative bacteria: Pseudomonas aeruginosa, Escherichia coli, Shigella dysenteriae, S. sonnei, Salmonella typhi, S. paratyphi and Vibrio cholerae. In addition, 7 pathogenic fungi: Aspergillus niger, Blastomyces dermatitidis, Candida albicans, Pityrosporum ovale, Trichophyton sp., Microsporum sp. and Cryptococcus neoformans were used in this study. All the microorganisms were collected from the Microbiology Lab., Department of Pharmacy, BGC Trust University, Chittagong, Bangladesh.

Preparation of media for antibacterial, antifungal and MIC test

To prepare nutrient agar (NA), saboured dextrose (SD) and nutrient broth (NB) media for antibacterial, antifungal and MIC tests: $24 \mathrm{~g} \mathrm{NA}$, $65 \mathrm{~g} \mathrm{SD}$ and $13 \mathrm{~g}$ of NB were dissolved in 1000 $\mathrm{mL}$ of distilled water and adjusted to $\mathrm{pH} 7.4 \pm 0.2$ and sterilized by autoclaving at $121{ }^{\circ} \mathrm{C}$ for 15 min at 15 psi pressure (Ananthanarayanan and Paniker 2000). The source of media was Hi-Media Laboratories Ltd., India.

\section{Antimicrobial Screening}

The antimicrobial activity of the ESL was evaluated by the disk diffusion method (Bauer et al. 1966), against 14 pathogens (11 bacteria and 7 fungi) using ciprofloxacin (CFN) and fluconazole (FCN) (Square Pharmaceuticals Ltd., Dhaka, Bangladesh), as standards for bacteria and fungi respectively. Three consecutive doses $(5,25$ and $50 \mu \mathrm{g} /$ disc) of ESL and a single dose $(30 \mu \mathrm{g} /$ disc $)$ for both standards were applied on $5 \mathrm{~mm}$ sterile paper disc. The results were read by presence or absence of zone of inhibition. The zone of inhibition $(\mathrm{mm})$ was then measured. Experiments were run in triplicate.

\section{Minimum inhibitory concentration (MIC)}

Micro-dilution method was used to determine the MICs of ESL. In this test, microorganisms are tested for their ability to produce visible growth 
on a series in dilution tubes (broth dilution). The lowest concentration of an antimicrobial agent that will inhibit the visible growth of a microorganism is known as the MIC (Andrews 2001).

\section{Brine shrimp lethality bioassay}

Brine shrimp lethality bioassay method (Meyer et al. 1982), was applied for the determination of cytotoxic activity of ESL. Dimethyl sulfoxide (DMSO) solutions (serially diluted) of the samples (ESL and VS) were applied against Artemia salina in a 1 day ex vivo assay. Vincristine sulfate (VS) (Gedeon Richter Ltd. Bangladesh) was used as standard. Experiments were run in triplicate with different concentrations $(10.5,9.0,7.5,6.0,4.4$, $3.0,1.5,0.75,0.375$ and $\left.0.187 \mu \mathrm{g} \mathrm{mL}^{-1}\right)$.

\section{Statistics}

Data obtained are reported as the mean $\pm \mathrm{SD}$ (standard deviation) and were followed by $t$-Student- NewmanKeuls as post hoc test. Differences were considered to be statistically significant when $p<0.01$.

\section{Cytotoxicity Against TUMor CELl Lines}

The samples used for estragole in cytotoxicity tests were diluted in sterile pure DMSO and tested at a concentration of $25 \mu \mathrm{g} \mathrm{mL}^{-1}$. Tumor cell lines used were MCF7 (breast carcinoma), NCI H 292 (lung carcinoma), and HEP-2 (laryngeal carcinoma) obtained from Rio de Janeiro Cell Bank (RJBrazil). All cancer cells were maintained in RPMI 1640 medium supplemented with $10 \%$ fetal bovine serum, $2 \mathrm{mM}$ glutamine, $100 \mathrm{U} \mathrm{mL}^{-1}$ penicillin, $100 \mathrm{mg} \mathrm{mL}^{-1}$ streptomycin at $37^{\circ} \mathrm{C}$ with $5 \% \mathrm{CO}_{2}$. For all experiments, $190 \mu \mathrm{l}$ of tumor cells were plated in $96-$ well plates $\left(10^{5}\right.$ cells $/ \mathrm{ml}$ for adherent cells or $3 \times 10^{5}$ cells $/ \mathrm{mL}$ for leukemias). Tested compounds $\left(0.1-25 \mathrm{mg} \mathrm{mL}^{-1}\right)$ dissolved in DMSO $1 \%$ were added to each well and incubated for $72 \mathrm{~h}$. Control groups received the same amount of DMSO. After $69 \mathrm{~h}$ of treatment $25 \mathrm{~mL}$ of MTT $\left(5 \mathrm{mg} \mathrm{mL}^{-1}\right)$ was added, three hours later, the MTT formazan product was dissolved in $100 \mathrm{~mL}$ of DMSO, and absorbance was measured at $595 \mathrm{~nm}$ in plate spectrophotometer (Berridge 1996). The $\mathrm{IC}_{50}$ values and their $95 \%$ confidence intervals for two different experiments were obtained by nonlinear regression using GraphPad Prism version 5.0 for Windows (GraphPad Software, San Diego, California USA). Doxorubicin was used as positive control for the tested cell lines.

\section{Statistics}

The obtained data was evaluated by one-way analysis of variance (ANOVA) followed by Student Newman Keuls test. In all cases, differences were considered significant if $p<0.05$, the means and respective standard errors were analyzed using the software Graph Pad Prism version 5.0 (GraphPad Software Incorporated, San Diego, USA). An intensity scale was used to assess the cytotoxic potential of the tested samples. Samples without activity (1-20\% inhibition), with little activity (cell growth inhibition ranging from 20 to 50\%), moderate activity (cell growth inhibition ranging from 50 to $70 \%$ ) and with a lot of activity (inhibition of growth varying from 70 to $100 \%$ ).

\section{RESULTS AND DISCUSSION}

Identification of essential oil components was performed by comparison of their retention indices GC-MS. The spectra were considered coincident if the similarity index was above $95 \%$. The yields of essential oil obtained by steam distillation of the leaves $200 \mathrm{~g}$ were $1.8 \%$. Table I shows the chemical composition and retention indices of the compounds identified. The chromatogram of the essential oil of $C$. zehntneri showed that seven peaks were detected and identified a total of seven compounds. Were identified $100 \%$ of chemical constituents (Figure 2, Table I) among monoand sesquiterpenes, being recognized as a major component estragole, representing $84.7 \%$ of the essential oil content. 


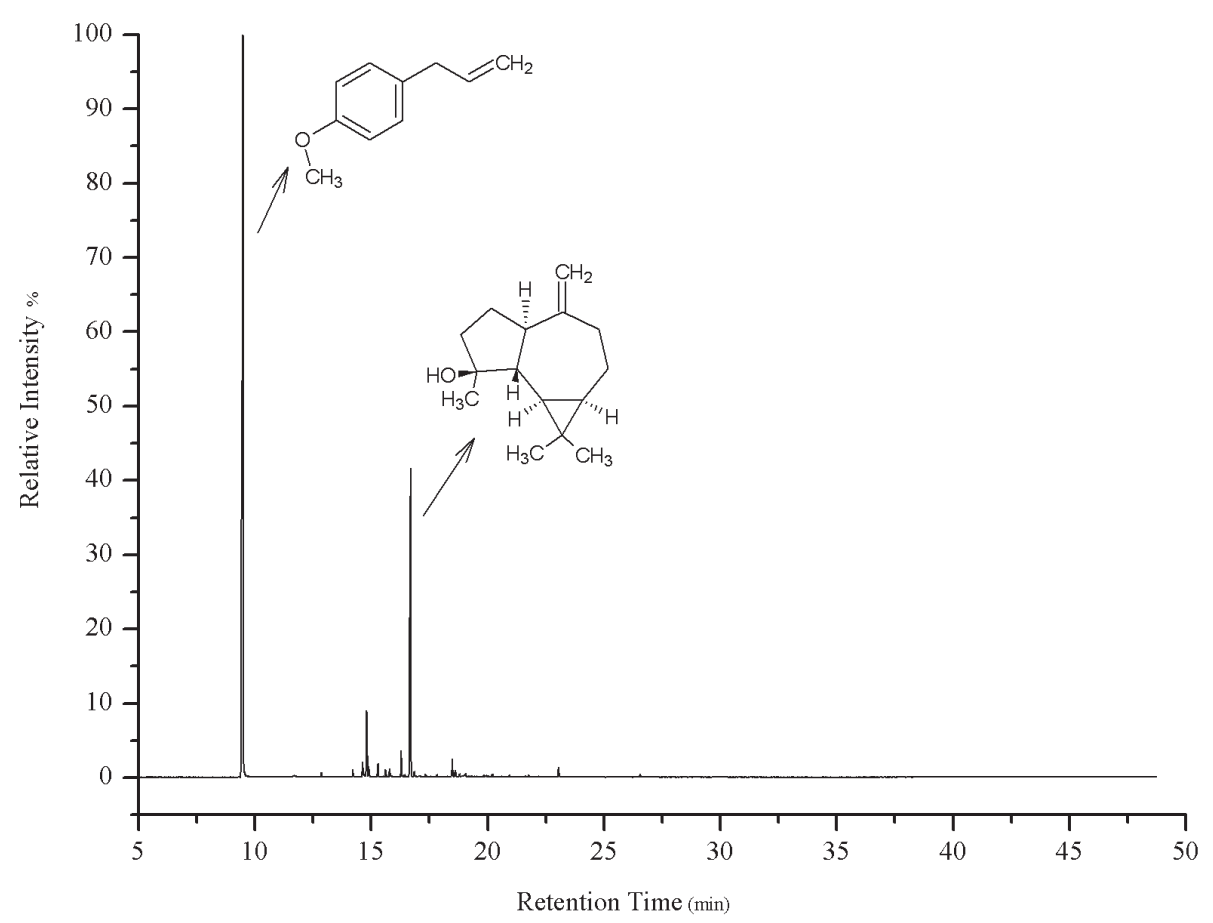

Figura 2 - Chromatographic profile (GC-MS) of the essential oil of the Croton zehntneri leaves.

TABLE I

Main components of the essential oil of the Croton zehntneri leaves.

\begin{tabular}{lcc}
\hline Compound & Retention time $/ \mathbf{m i n}$ & Perceptual area $\%$ \\
\hline 1,8 cineole & 4.53 & 0.3 \\
Estragole & 9.39 & 84.7 \\
Anisaldehyde & 10.58 & 1.6 \\
3(2H)-Benzofuranone, 2,4-dimethyl- & 18.13 & 3.2 \\
(+) Spathulenol & 18.29 & 5.6 \\
Aromadendrene & 18.40 & 3.1 \\
Methyl farnesoate & 22.76 & 1.5 \\
\hline & & $\mathbf{1 0 0}$ \\
\hline
\end{tabular}

According to literature (Morais et al. 2006, Santos et al. 2010), there are variations in the concentration of chemical constituents majority of C. zehntneri essential oil according to origin. Thus, this species was characterized in four chemical types: anethole (i) - for specimens collected in Fortaleza (CE) and Viçosa Ceara (CE), eugenol (ii) - for those collected in Areia Branca (RN) and Quixadá (EC); methyleugenol (iii) - for specimens collected in the Ipu (CE) and Oeiras (PI); estragole (iv) - for specimens collected in Tianguá (CE),

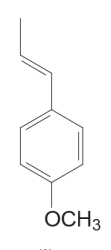

(i)

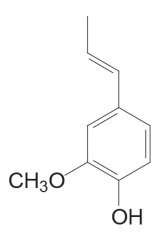

(ii)

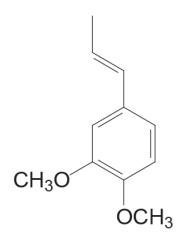

(iii)

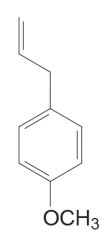

(iv)
Salitre (CE) and Granja (CE). When compared to literature data, our study evidenced some differences in the chromatographic profile (GCMS) as well as in quantitative composition and yield (about $1.8 \%$ ) of esential oil C. zehntneri. 
A large variety of commercial antibiotics are used to control infectious diseases. These may cause severe hypersensitivity reactions and lead to resistance to the pathogenic microorganisms. Next to the threat of drug resistance, and other infection related phenomena, there is a growing consumer demand for new chemicals. Furthermore, there is increasing legislation against the use of these, especially of chemical antimicrobials. It is, therefore, necessary to develop alternative agents and safe methods for controlling said diseases.

In the antibacterial and antifungal sensitivity test (Table II), the highest zone of inhibition (15.76 $\mathrm{mm}$ ) was found against Microsporum sp. by the ESL at concentration $50 \mu \mathrm{g} /$ disc. This was followed by $15.25,14.81,14.53,14.53,14.53,14.33,13.43,13.27$, $13.12,13.09$ and $12.12 \mathrm{~mm}$ against $B$. megaterium, $B$. subtilis, $S$. aureus, $S$. sonnei, $S$. paratyphi, $C$. neoformans, B. cereus, P. ovale, C. albicans, $B$. dermatitidis and $V$. cholerae respectively. But it was inactive against $P$. aeruginosa, Trichophyton sp., $S$. dysenteriae, S. typhi, A. niger and E. Coli.

The diameter of inhibition zone is expressed as Mean $\pm \mathrm{SD}(n=3)$; Ni: zone diameter less than 8 $\mathrm{mm}$ was considered inactive.

ESL at the dose of $25 \mu \mathrm{g} /$ disc produced the highest zone of inhibition $(13.65 \mathrm{~mm})$ against $C$. neoformans. Then followed by 13.33, 12.65, 12.35 and 12.31 against $B$. subtilis, $S$. aureus, $S$. paratyphi and $B$. megaterium respectively. Test dose was inactive against other test pathogens. Estragole at $5 \mu \mathrm{g} /$ disc produced no inhibition to the tested organisms (Table II).

In this study, it was found that doses of 25 and $50 \mu \mathrm{g} /$ disc showed a potential activity against the evaluated gram positive strains. However, against Gram-negative bacteria the inhibitory level was reduced or absent. The reduced inhibitory activity

TABLE II

Antimicrobial sensitivity of ESL.

\begin{tabular}{|c|c|c|c|c|}
\hline \multirow[t]{3}{*}{$\begin{array}{c}\text { Test microorganisms } \\
\end{array}$} & \multicolumn{4}{|c|}{ Inhibition zone diameter $/ \mathrm{mm}$} \\
\hline & \multicolumn{3}{|c|}{ ESL per disc } & \multirow{2}{*}{$\begin{array}{c}\text { Standards } \\
(30 \mu \mathrm{g} / \text { disc }) \\
\mathrm{CFN}\end{array}$} \\
\hline & $(5 \mu g)$ & $(25 \mu g)$ & $(50 \mu g)$ & \\
\hline B. subtilis & $\mathrm{Ni}$ & $13.33 \pm 0.42$ & $14.81 \pm 0.65$ & $18.01 \pm 0.12$ \\
\hline B. megaterium & $\mathrm{Ni}$ & $12.31 \pm 0.62$ & $15.25 \pm 0.37$ & $19.67 \pm 0.33$ \\
\hline B. cereus & $\mathrm{Ni}$ & $\mathrm{Ni}$ & $13.43 \pm 0.57$ & $18.21 \pm 0.49$ \\
\hline S. aureus & $\mathrm{Ni}$ & $12.65 \pm 0.25$ & $14.53 \pm 0.25$ & $19.77 \pm 0.44$ \\
\hline \multicolumn{5}{|l|}{ Gram (-) bacteria } \\
\hline P. aeruginosa & $\mathrm{Ni}$ & $\mathrm{Ni}$ & $\mathrm{Ni}$ & $17.33 \pm 0.63$ \\
\hline E. coli & $\mathrm{Ni}$ & $\mathrm{Ni}$ & $\mathrm{Ni}$ & $16.91 \pm 0.25$ \\
\hline S. dysenteriae & $\mathrm{Ni}$ & $\mathrm{Ni}$ & $\mathrm{Ni}$ & $17.67 \pm 0.37$ \\
\hline S. sonnei & $\mathrm{Ni}$ & $\mathrm{Ni}$ & $14.53 \pm 0.21$ & $19.17 \pm 0.17$ \\
\hline S. typhi & $\mathrm{Ni}$ & $\mathrm{Ni}$ & $\mathrm{Ni}$ & $16.71 \pm 0.42$ \\
\hline V. cholera & $\mathrm{Ni}$ & $\mathrm{Ni}$ & $12.12 \pm 0.42$ & $18.41 \pm 0.32$ \\
\hline S. paratyphi & $\mathrm{Ni}$ & $12.35 \pm 0.85$ & $14.53 \pm 0.37$ & $18.25 \pm 0.17$ \\
\hline Fungi & & & & $\mathrm{FCN}$ \\
\hline A. niger & $\mathrm{Ni}$ & $\mathrm{Ni}$ & $\mathrm{Ni}$ & $17.37 \pm 0.37$ \\
\hline B. dermatitidis & $\mathrm{Ni}$ & $\mathrm{Ni}$ & $13.09 \pm 0.42$ & $17.01 \pm 0.32$ \\
\hline C. albicans & $\mathrm{Ni}$ & $\mathrm{Ni}$ & $13.12 \pm 0.63$ & $17.97 \pm 0.69$ \\
\hline P. ovale & $\mathrm{Ni}$ & $\mathrm{Ni}$ & $13.27 \pm 0.17$ & $18.93 \pm 0.37$ \\
\hline Trichophyton sp. & $\mathrm{Ni}$ & $\mathrm{Ni}$ & $\mathrm{Ni}$ & $17.43 \pm 0.21$ \\
\hline Microsporum sp. & $\mathrm{Ni}$ & $\mathrm{Ni}$ & $15.76 \pm 0.21$ & $18.10 \pm 0.53$ \\
\hline C. neoformans & $\mathrm{Ni}$ & $13.65 \pm 0.35$ & $14.33 \pm 0.47$ & $16.25 \pm 0.47$ \\
\hline
\end{tabular}

The diameter of inhibition zone is expressed as Mean $\pm \mathrm{SD}(n=3)$; Ni: zone diameter less than $8 \mathrm{~mm}$ was considered inactive. 
of estragole on the Gram-negative bacteria can be justified because its outer lipopolysaccharide membrane rich, responsible for the hydrophilic character of the surface, hindering the penetration of hydrophobic substances such as estragole (Dorman and Deans 2000).

In this study five species of fungi showed satisfactory zone inhibition (Table II). According to Fontenelle et al. 2008, the essential oil of $C$. zenhteneri, specimen collected in the State of Ceara - Brazil, whose main component was estragole $(72.9 \%)$, showed activity against some strains of fungi, however, this has not been definitively assigned to estragole. As ESL showed good antifungal activity, and it's a substance from a common aromatic plant in our community, it would the use of this compound in the search for new antifungal that can replace synthetic drugs that cause drawbacks in terms of toxicity, and cost effectiveness.

In MIC by serial tube dilution method, a potent MIC $\left(38.52 \mu \mathrm{g} \mathrm{mL}^{-1}\right)$ was shown by ESL against $S$. paratyphi. The MIC of $58.75,58.75$, 61.54, 63.15, 63.43, 88.51, 131.2 and $145.0 \mu \mathrm{g}$ $\mathrm{mL}^{-1}$ was found against $B$. subtilis, $C$. albicans, $P$. ovale, B. megaterium, $S$. sonnei, C. neoformans, $B$. dermatitidis and $S$. aureus, respectively. However, there was no inhibition to the other test pathogens (Table III).

TABLE III

Minimum inhibitory concentrations (MICs) by ESL.

\begin{tabular}{cc}
\hline Test pathogens & MICs/ $\left(\boldsymbol{\mu g} \mathbf{~ m L}^{-1}\right)$ \\
\hline B. Subtilis & 58.75 \\
B. Megaterium & 63.15 \\
S. aureus & 145.0 \\
S. Sonnei & 63.43 \\
S. Paratyphi & 38.52 \\
B. Dermatitidis & 131.2 \\
C. albicans & 58.75 \\
P. Ovale & 61.54 \\
C. Neoformans & 88.51 \\
\hline
\end{tabular}

The monoterpenes, found in essential oils of citrus fruits, cherry, mint, and herbs, are non-nutritive dietary microconstituents mainly responsible for the distinctive fragrance of many plants. They are used as flavor additives in food, beverages, and perfumes. Recent studies have shown that monoterpenes exert antitumor activities, and suggest that these components can be a new class of chemotherapeutic agents (Elson and Yu 1994, Kellof et al. 1996, Crowell 1999).

Toxicity studies using A. salina has been suggest at many compounds with biological activity to determine its potential therapeutic application (Parra et al. 2001). $\mathrm{LC}_{50}$ and $\mathrm{LC}_{90}$ greater than $250 \mu \mathrm{g} \mathrm{mL}^{-1}$ are considered to have low toxicity; between 80 and $250 \mu \mathrm{g} \mathrm{mL}^{-1}$ moderately toxic, and $\mathrm{LC}_{50}$ and $\mathrm{LC}_{90}$ less than $80 \mu \mathrm{g} \mathrm{mL}^{-1}$ are considered toxic (Carballo et al. 2002). In Table IV, all the $\mathrm{LC}_{50}$ estragole and Vincristine Sulfate, which is a widely used chemotherapeutic agent. Sulgate are shown the ESL increases the mortality rate of alive brine shrimps with the increasing order of doses. The test sample (estragole) showed potent citoxicity response when compared to the standard, VS. There is a dose response relationship between the mortality percentage and drug dilutions.

McLaughlin et al. (1998) reported that the brine shrimp assay shows good correlation with cytotoxic activity in certain human solid tumors, suggesting a first step to evaluate the potential anti-tumor agents. Although it has been demonstrated that ESL presents significant results, as shown in Table IV, when compared to Vincristine Sulfate, its inhibition was not satisfactory against human cells (MCF-7, HEp2, NCIH292) in this study, using other assay.

Aiming to evaluate estragole and/EO as a chemotherapeutic agent, we decided to examine their toxicity on three tumor cell lines MCF7 and NCI H 292 and HEP-2 at a concentration of $25 \mu \mathrm{g} \mathrm{mL}^{-1}$. The toxicity $A$. saline cannot be directly extrapolated to the toxicity in humans, since humans and other mammals have physiological media to remove toxic substances (Siqueira et al. 1998). 
TABLE IV

Percent inhibition of cell growth (IC\%) in three tumor cell lines $\left(25 \mu \mathrm{g} \mathrm{mL}^{-1}\right)$.

\begin{tabular}{ccc}
\hline Samples & $\mathbf{L C}_{\mathbf{5 0}}\left(\boldsymbol{\mu g} \mathbf{~ m L}^{-\mathbf{1}}\right)$ & $\mathbf{L C}_{\mathbf{9 0}}\left(\boldsymbol{\mu g} \mathbf{~ m L}^{-\mathbf{1}}\right)$ \\
\hline $\mathrm{ESL}$ & $4.54 \pm 0.21^{*}$ & $8.47 \pm 0.42^{*}$ \\
$\mathrm{VS}$ & $0.37 \pm 0.02$ & $0.71 \pm 0.15$ \\
\hline
\end{tabular}

${ }^{*} p<0.01$; ESL: Estragol; VS: Vincritistine sulphate (control positive).

Analyzing samples of essential oil of $C$. zehntneri and estragole (Table V), it can be seen that all strains tested showed inhibition percentage lower than $20 \%$. Given the results presented we inferred that estragole (main component of the essential oil of C. zehntneri collected in Simões State of Piauí ) has no inhibitory activity on tumor cell lines at the dose tested.

The test of $A$. Saline is not specific as antitumor guidance or for any physiological action in particular, but can be used in monitoring the fractionation of extracts, as suggested by Meyer et al. (1982). Therefore, substances with $\mathrm{LC}_{50} \leq 4.54$ $\mu \mathrm{g} \mathrm{mL}{ }^{-1}$ calculated in our experiment may indicate the existence of other biological activities. The dose $25 \mu \mathrm{g} \mathrm{mL}^{-1}$ has been used by other authors (Da Silva and Albuquerque 2011) as an average value for assessing the potential of cellular inhibition.

We present a classical purification methodology of estragole from essential oil of C. zehntneri (from Simoes - State of Piauí), however more recently (Aguiar et al. 2014) our group has shown that this percentage can reach up to about $100 \%$ when leaf samples were collected in February 2011, flowering period. Therefore, due to the wide application and toxicity the species in study is characterized as an alternative and viable source of estragole.

\section{CONCLUSION}

In summary, when compared to literature data, our study evidenced some differences in the chromatographic profile (GC-MS) as well as in the quantitative composition $(1.8 \%$ yield) of essential oil $C$. zehntneri. The estragole (ESL) in this study showed significant antimicrobial as well as cytotoxic activities against $A$. salina, however, it does not prossess inhibitory activity on tumor cell lines at the dose tested. Due to the importance of that compound, the species $C$. zehntneri may be a potential alternative source of estragole, because of its good yield. The antimicrobial activity of ESL is a new candidate for future studies of synergism, compatibility, and mechanism of action.

It is important to mention that this specie has wide distribution in the "Serra de Simões" community, it is frequently used as tea, and their main component (estragole) has extensive potential therapeutic application, but can to present carcinogenic and genotoxic potential, as indicated by the report of the European Union, Committee on Herbal Medicinal Products.

\section{ACKNOWLEDGMENTS}

The authors are grateful to Universidade Federal do Piauí (UFPI) and Coordenação de

TABLE V

Percent inhibition of cell growth (IC\%) in three tumor cell lines $\left(25 \mu \mathrm{g} \mathrm{mL}^{-1}\right)$.

\begin{tabular}{l|cc|cc|cc}
\hline \multirow{2}{*}{ Sample } & \multicolumn{2}{|c|}{ MCF-7 } & \multicolumn{2}{c|}{ HEP-2 } & \multicolumn{2}{c}{ NCIH292 } \\
\cline { 2 - 7 } & Inhibition (\%) & Deviation & Inhibition (\%) & Deviation & Inhibition (\%) & Deviation \\
\hline Estragole & 4.62 & 1.25 & 0 & 0 & 7,36 & 2.72 \\
EO & 0 & 0 & 0 & 0 & 16.35 & 5.5 \\
Doxorrubicina & 60.08 & 3.26 & 78.12 & 2.74 & 87.92 & 2.84 \\
\hline
\end{tabular}

EO: Essential oil of leaves from C. Zenhtneri. 
Aperfeiçoamento de Pessoal de Nível Superior (CAPES) for their financial support and research fellowships and to LAGO - UFPI for analysis.

\section{RESUMO}

Croton zehntneri (Euphorbiaceae) é uma planta aromática nativa da região Nordeste do Brasil. O monoterpenóide Estragol (ESL) foi isolado por métodos cromatográficos clássicos a partir do óleo essencial (OE) das folhas de C. zehntneri e caracterizado por CG-DIC e CG-EM, tendo seu potencial antimicrobiano e citotóxico avaliado. A análise do OE permitiu a identificação de $100 \%$ dos constituintes integrados, cujo rendimento foi cerca de $1.8 \%$. Os principais componentes identificados foram: eucaliptol, estragol (84.7\%) e espatulenol. A dosagem de $50 \mu \mathrm{g} /$ disco de ESL apresentou halos de inibição bastante expressivos frente a bactérias gram positiva e fungos. O ESL apresentou toxicidade frente a Artemia salina com $\mathrm{CL}_{50}$ e $\mathrm{CL}_{90}$ de 4,54 e 8,47 $\mu \mathrm{g} \mathrm{mL}^{-1}$. Entretanto, nos testes de inibição tumoral (células humanas), não houve inibição satisfatória em nenhuma das linhagens de células humanas cancerígenas (MCF-7, HEP-2 e NCIH292).

Palavras-chave: Antimicrobiana, Croton zehntneri, citotóxico, estragol.

\section{REFERENCES}

AGUIAR UM, DE LIMA SG, ROCHA MS, FREITAS RM, OLIVEIRA TM, SILVA RM, Moura LCB AND ALMEIDA LTG. 2014. Preparação e caracterização do complexo de inclusão do óleo essencial de croton zehntnericom $\beta$-ciclodextrina. Quím Nova 37: 50.

ADAMS RP. 2007. Identification of essential oil Components by gas chromatography/mass spectrometry, n.4, Allured Publishing Corporation: Carol Stream, IL, USA.

ANANTHANARAYANAN RAND PANIKER CJK. 2000. Text book of Micro-biology, n.6, Chennai: Orient Longman Ltd, 581 p.

ANDREWS JM. 2001. Determination of minimum inhibitory concentrations. J Antimicrob Chemother 48: 5.

BAuer AW, Kirby WM, Sheriss JC AND TURCK M. 1996. Antibiotic susceptibility testing by standardized single method. Am J Clin Pathol 45: 493.

BounAmama H, NoEl T, Villard J, BENHARREF A AND JANA M. 2006. Antimicrobial activities of the leaf extract of two Moroccan Cistus L. species. J Ethnopharmacol 104: 104.

BERridge MV, TAN AS, MCCOY KD AND WANG R. 1996. The biochemical and cellular basis of cell proliferation assays that use tetrazolium salts. Biochemica 4: 19.
Carballo JL, Hernandez - InCA SL, Perez P AND Garcia GRAVALLO MD. 2002. A comparison between two brine shrimp assays to detectin vitro cytotoxicity in marine natural products. BMC Biotechnol 2: 17.

Crowell PL. 1999. Prevention and therapy of cancer by dietary monoterpenes. J Nutr 129: 775.

Da Silva CC AND AlbuQuerque JFC. 2011. Determinação da atividade citotóxica do extrato etanólico do caule de Hyptis pectanata (L.) Poit. Disponível em http://www. contabeis.ufpe.br/propesq/images/conic/2011/conic/ npibic/40/114031096SCNP.pdf, acessado em 30/04/2013.

DE ClercQ E. 2001. New developments in anti-HIV chemotherapy. Farmaco 56: 3.

Dorman HJD AND DEANS SG. 2000. Antimicrobial agents from plants: antibacterial activity of plant volatile oils. J Appl Microbiol 88: 308.

EMORI TC AND GAYNES R. 1993. An overview of nosocomial infections, including the role of the microbiology laboratory. Clin Microb Review 6: 428.

ELSON CE AND YU SG. 1994. The chemoprevention of cancer by mevalonate derived constituents of fruits and vegetables. J Nutr 124: 607.

Fontenelle ROS, MORAIS SM, BRITO EHS, BRILlHANTE RSN, CORDEIRO RA, NASCIMENTO NRF, KERNTOPF MR, SidRIM JJC AND RochA MFG. 2008. J Appl Microbiol 104: 1383 .

IZEVBIGIE EB. 2003. Discovery of Water-Soluble Anticancer Agents (Edotides) from a Vegetable Found in Benin City, Nigeria. Exp Biol Med 228: 293.

Jeu L, Piacenti FJ, LyakHovetskiy AG AND Fung HB. 2003. Voriconazole. Clin Ther 25: 1321.

Kellof GJ, Boone CW, Crowell JA, Steele VE, Lubet RA, Doody LA, Malone WF, HaWk ET AND Sigman CC. 1996. New agents for cancer chemoprevention. J Cell Biochem 26: 1.

MedeIROS LBP ET AL. 2012. Chemical constituents and evaluation of cytotoxic and antifungal activity of Lantana camara essential oils. J Pharmacogn 22: 1259.

Meyer BN, Ferringni NR, PuAm JE, LACOBSEn LB, Nichols DE AND MCLAughlin J. 1982. A convenient general bioassay for active constituents. Planta Med 45: 31 .

Morais SM, CATUNDA-JUNIOR FEAC, DA SILVA ARA, Neto JSM, Rondina D AND LEAL-CARdoso JH. 2006. Antioxidant activity of essential oils from Northeastern Brazilian Croton species. Quím Nova 29: 907-910.

McLaughlin JL, Rogers LL AND ANDERson JE. 1998. The Use of Biological Assays to Evaluate Botanicals. Drug Inf J 32: 513-524.

OKEMO PO, BAIS HP AND VIVANCO JM. 2003. In vitro activities of Maesa lanceolata extracts against fungal plant pathogens. Fitoterp 74: 312.

PARRA AL, Silva YR AND Iglesia BL. 2001. Acute and subacute toxicity (28 days) of a mixture of ursolic acid and oleanolic acid obtained from Bouvardia ternifolia in mice. Phytomedicine 8: 395.

PoOLE KJ. 2001. Overcoming antimicrobial resistance by targeting resistance mechanisms. Pharm Pharmacol 53: 283. 
SANTOS HS, FURTAdO EF, BERTINI LM, BANDEIRA PN, Albuquerque MrJR, MENESES JESA, TREVISAN MTS AND LEMOS TG. 2010. Chemical composition and cholinesterase inhibition of essential oils of three chemotypes from Croton zehntneri. Rev Latinoamer Quím 38: 583.

SILVER L AND Bostian K. 1990. Screening of natural products for antimicrobial agents. Eur J Clin Microbiol Infect Dis 9: 455.

SiqueIRA MJ, Bomm DM, PEREIRA GFN, GARCEZ SW AND BOAVENTURA MAD. 1998. Estudo fifitoquímico de Unonopsis lindmanii - Annonaceae, biomonitorado pelo ensaio de toxicidade sobre a Artemia salina leach. Quím Nova 21: 557.
TAYlor PW, Stapleton PD AND PaUl LuZio J. 2002. New ways to treat bacterial infections. Drug Discov Today 7: 1086 .

Zampini IC, Cuello S, Alberto MR, Ordonez RM, AlmeidA RD, SOLORZANo E AND ISLA MI. 2009. Antimicrobial activity of selected plant species from the Argentine puna against sensitive and multi-resistant bacteria. J Ethnopharmacol 124: 499. 